\title{
Nitric oxide/cyclic guanosine monophosphate inducers sodium nitroprusside and L-arginine inhibit the proliferation of gastric cancer cells via the activation of type II cyclic guanosine monophosphate-dependent protein kinase
}

\author{
XIAOYUAN YAO, YAN WU, MIAOLIN ZHU, HAI QIAN and YONGCHANG CHEN
}

Department of Physiology, School of Medicine, Jiangsu University, Zhenjiang, Jiangsu 212013, P.R. China

Received May 20, 2014; Accepted May 7, 2015

DOI: $10.3892 / \mathrm{ol} .2015 .3229$

\begin{abstract}
Nitric oxide (NO) may activate soluble guanylyl cyclase (sGC), resulting in the increase of intracellular cyclic guanosine monophosphate (cGMP), a key molecule in the activation of type II cGMP-dependent protein kinase (PKG II). In our previous study, the membrane-permeable cGMP analogue 8-pCPT-cGMP was used to activate PKG II. The aim of the present study was to investigate whether NO/sGC-induced endogenous cGMP is able to activate PKG II and induce the corresponding effects. In the AGS gastric cancer cell line, the expression of PKG II was increased by infecting the cells with an adenoviral construct encoding PKG II cDNA (Ad-PKG II) and the activation of PKG II was induced by 8-pCPT-cGMP (positive control), the NO donor sodium nitroprusside (SNP) and the NO precursor L-arginine. ELISA was performed to detect the concentration of cGMP in AGS cells and the Cell Counting Kit-8 was used to analyze the proliferation of differently treated cells. Western blot analysis was used to detect the expression and phosphorylation of associated proteins. The results demonstrated that the level of cGMP was increased in cells treated with the NO donor or precursor. There was an obvious increase of Ser239 phosphorylation of the vasodilator-stimulated phosphoprotein, representing the increase in the activity of PKG II. The epidermal growth factor (EGF)-induced proliferation of AGS cells was inhibited by infection with Ad-PKG II and treatment with SNP or L-arginine. In addition, EGF-induced tyrosine phosphorylation of the EGF receptor (EGFR) and tyrosine/serine phosphorylation of extracellular signal-regulated kinase (ERK) were also inhibited by infection with Ad-PKG II and treatment with the
\end{abstract}

Correspondence to: Dr Yan Wu or Professor Yongchang Chen, Department of Physiology, School of Medicine, Jiangsu University, 301 Xuefu Road, Zhenjiang, Jiangsu 212013, P.R. China

E-mail:wuyan81@ujs.edu.cn

E-mail: ycchen54@ujs.edu.cn

Key words: sodium nitroprusside, L-arginine, type II cyclic guanosine monophosphate-dependent protein kinase, proliferation, gastric cancer cells
NO donor or precursor. These data indicated that NO donors and precursors may activate the expression of PKG II, thereby blocking EGF-initiated signaling of the mitogen-activated protein kinase/ERK pathway and inhibiting EGF-induced proliferative activity through preventing the phosphorylation of EGFR at Tyr1068.

\section{Introduction}

Nitric oxide (NO) is synthesized in a variety of tissues and displays various physiological actions via activating soluble guanylyl cyclase (sGC), which converts guanosine triphosphate (GTP) to cyclic guanosine monophosphate (cGMP), thereby leading to an increase in the intracellular concentration of cGMP (1). cGMP is an important secondary messenger and exerts its effects through activating cGMP-dependent protein kinases (PKGs). To date, two types of PKGs have been identified in mammalian cells, namely PKG I and II. The activated PKGs exert their biological effects through phosphorylating target proteins $(2,3)$. The target proteins of PKGs have attracted significant attention and, in particular, the significance of PKG II and its target proteins is currently a major research focus. Epidermal growth factor receptor (EGFR) is a receptor tyrosine kinase with a molecular weight of $170 \mathrm{kDa}$. Activated EGFR may initiate the signal transduction of several pathways, including mitogen-activated protein kinase (MAPK) pathway-mediated proliferation $(4,5)$. Our previous studies demonstrated that, when PKG II is highly expressed through infecting the cells with an adenoviral construct encoding PKG II cDNA (Ad-PKG II), and activated by cGMP, the proliferation of gastric cancer cells is inhibited $(6,7)$. The mechanism of the inhibitory effect of PKG II on the activation of EGFR is through blocking the tyrosine phosphorylation/activation of EGFR. During this process, the cell membrane-permeable cGMP analogue 8-pCPT-cGMP is required to activate PKG II $(8,9)$. NO is synthesized by NO-synthase (NOS) or released by NO donors; increased NO levels may activate sGC, leading to the increase of intracellular cGMP. In the present study, the effect of the NO donor sodium nitroprusside (SNP) and the NOS substrate L-arginine on the activation of PKG II and the proliferative activity and signaling of Ad-PKG II-infected gastric cancer cells was investigated. 


\section{Materials and methods}

Cell lines, antibodies and chemicals. The AGS human gastric cancer cell line was provided by the Institute of Cell Biology (Shanghai, China). Adenoviral vectors encoding the cDNA of $\beta$-galactosidase (Ad-LacZ) and PKG II (Ad-PKG II) were obtained from Dr Gerry Boss and Dr Renate Pilz (University of California, San Diego, CA, USA). Dulbecco's modified Eagle's medium (DMEM) and fetal bovine serum (FBS) were obtained from Gibco-BRL (Grand Island, NY, USA). The rabbit polyclonal antibody against PKG II was purchased from Abgent Biotechnology (San Diego, CA, USA; catalog no. AP8001a; dilution, 1:200). The goat polyclonal IgG antibody against phosphorylated vasodilator-stimulated phosphoprotein (p-VASP; Ser239; catalog no. sc-23507; dilution, 1:200) and the horseradish peroxidase (HRP)-conjugated mouse monoclonal $\mathrm{IgG}_{1}$ antibody against $\beta$-actin were obtained from Santa Cruz Biotechnology, Inc. (Dallas, TX, USA; catalog no. sc-47778; dilution, 1:1,000). Mouse anti-p-EGFR (Tyr1068) monoclonal antibody was purchased from Cell Signaling Technology, Inc. (Danvers, MA, USA; catalog no. 2236; dilution, 1:1,000.). Rabbit anti-p-ERK (Thr202/Tyr204) polyclonal antibody was obtained from Bioworld Technology (St. Louis Park, MN, USA; catalog no. BS5016; dilution, 1:500). The HRP-conjugated goat anti-mouse, goat anti-rabbit and rabbit anti-goat polyclonal IgG secondary antibodies (catalog nos. 115-035-003, 111-035-003 and 305-035-003, respectively; dilution, 1:10,000) were purchased from Jackson ImmunoResearch Laboratories (West Grove, PA, USA). The cellular membrane-permeable cGMP analog 8-pCPT-cGMP was obtained from Calbiochem (San Diego, CA, USA). EGF and SNP were purchased from Sigma-Aldrich (St. Louis, MO, USA). L-arginine was obtained from the Beyotime Institute of Biotechnology (Shanghai, China). Cell Counting Kit-8 (CCK-8) was obtained from R\&S Biotechnology (Shanghai, China). The human cGMP ELISA kit was obtained from Hushang Biotechnology (Shanghai, China) and the electrochemiluminescence (ECL) reagents were purchased from Millipore (Billerica, MA, USA).

Cell culture and treatment. The AGS cells were maintained in DMEM supplemented with 10\% FBS and penicillin $(100 \mathrm{IU} / \mathrm{ml}) /$ streptomycin $(100 \mathrm{mg} / \mathrm{ml})$ and incubated at $37^{\circ} \mathrm{C}$ in $5 \% \mathrm{CO}_{2}$. The medium was changed every 2 days and the cells were subcultured at confluence. The cells were seeded in 6 -well plates at a density of 70-80\% of confluence and were infected with Ad-LacZ or Ad-PKG II (with a multiplicity of infection of $100 \%$ ) or mock-infected the following day. At $24 \mathrm{~h}$ post-infection, the medium was replaced with serum-free medium and the culture was continued for $12 \mathrm{~h}$. The infected cells were incubated with $250 \mu \mathrm{M} 8$-pCPT-cGMP for $1 \mathrm{~h}$, the NO donor or precursor (1 $\mathrm{mM} \mathrm{SNP}$ for $2 \mathrm{~h}$ and $2 \mathrm{mM} \mathrm{L}$-arginine for $4 \mathrm{~h}$ ) and incubated with $100 \mathrm{ng} / \mathrm{ml}$ EGF for $5 \mathrm{~min}$.

CCK-8 assay. A total of 10,000 cells (in $150 \mu \mathrm{l}$ complete DMEM) were seeded in one well of a 96-well plate. Following attachment, the cells were infected with Ad-LacZ and Ad-PKG II for $24 \mathrm{~h}$. The cells were then washed and serum-starved overnight. Thereafter, the cells were incubated in the presence of 8-pCPT-cGMP $(250 \mu \mathrm{M})$ for $1 \mathrm{~h}$, SNP $(1 \mathrm{mM})$ for $2 \mathrm{~h}$ or L-arginine $(2 \mathrm{mM})$ for $4 \mathrm{~h}$, and then treated with EGF (100 ng/ml) for $24 \mathrm{~h}$. Approximately $10 \mu 1$ of CCK-8 dye was added to each well and the plate was incubated for $30 \mathrm{~min}$. The optical density (OD) at $450 \mathrm{~nm}$ was measured using an ELx800 Absorbance Reader (BioTek Instruments, Inc., Winooski, VT, USA). Data are presented as the relative proliferation, calculated by dividing the OD value of each group by the OD value of Ad-LacZ group.

ELISA. The differently treated cells were harvested by phosphate-buffered saline ( $\mathrm{pH}$ 7.2-7.4) to a concentration of $1 \mathrm{million} / \mathrm{ml}$. The collected cells were subjected to three freeze-thaw cycles to further break the cell membranes. Subsequently, the samples were centrifuged for $20 \mathrm{~min}$ at 0.4-0.9 $\mathrm{x} \mathrm{g}$. The collected supernatants were processed using the human cGMP ELISA kit, according to the manufacturer's instructions. The absorbance was determined at $450 \mathrm{~nm}$ using the ELx800 Absorbance Reader. The standard curve was constructed by plotting the absorbance for each standard on the $\mathrm{x}$-axis against the concentrations on the $\mathrm{y}$-axis; the sample concentrations were calculated according to the sample OD value and the standard curve.

Western blotting. The protein samples were subjected to SDS-PAGE (8-12\%) according to the molecular size of the target protein and transferred onto a polyvinylidene difluoride (PVDF) membrane. The PVDF membranes were blocked using 5\% non-fat milk in Tris-buffered saline with Tween (TBS-T) for $1 \mathrm{~h}$ at room temperature. Incubation with the primary antibodies was performed at $4^{\circ} \mathrm{C}$ overnight, followed by incubation with the corresponding secondary antibodies at room temperature for $1 \mathrm{~h}$, with three washes in TBS-T $(0.1 \%$ Tween 20) subsequent to each incubation. The signal was visualized using ECL detection reagents.

Statistical analysis. Data are expressed as means \pm standard deviation. Statistical analysis was performed using a two-tailed analysis of variance with SPSS 15.0 statistical software (SPSS, Inc., Chicago, IL, USA). $\mathrm{P}<0.05$ was considered to indicate a statistically significant difference.

\section{Results}

SNP and L-arginine inhibit the proliferation of AGS cells expressing high levels of PKG II. AGS cells were infected with Ad-PKG II to increase the expression of the PKG II protein. SNP or L-arginine was added to the culture medium to activate PKG II. The proliferative activity of the cells was evaluated with CCK-8. The results demonstrated that, in cells infected with Ad-LacZ (control virus) and treated with EGF $(100 \mathrm{ng} / \mathrm{ml}, 24 \mathrm{~h})$, there was a significant increase in proliferative activity compared with cells infected with Ad-LacZ alone $(\mathrm{P}<0.01$, Fig. 1$)$. In cells infected with Ad-PKG II, treated with 8-pCPT-cGMP ( $250 \mu \mathrm{M}, 1 \mathrm{~h})$ and then treated with EGF $(100 \mathrm{ng} / \mathrm{ml}, 24 \mathrm{~h})$, the proliferative activity was markedly inhibited. In cells infected with Ad-LacZ, treated with SNP $(1 \mathrm{mM}, 2 \mathrm{~h})$ or L-arginine $(2 \mathrm{mM}, 4 \mathrm{~h})$ and then with EGF $(100 \mathrm{ng} / \mathrm{ml}, 24 \mathrm{~h})$, the proliferation was partially inhibited. However, in cells infected with Ad-PKG II, treated with SNP $(1 \mathrm{mM}, 2 \mathrm{~h})$ or L-arginine $(2 \mathrm{mM}, 4 \mathrm{~h})$, and then treated with EGF (100 ng/ml, $24 \mathrm{~h}$ ), significant inhibition of EGF-induced 
A

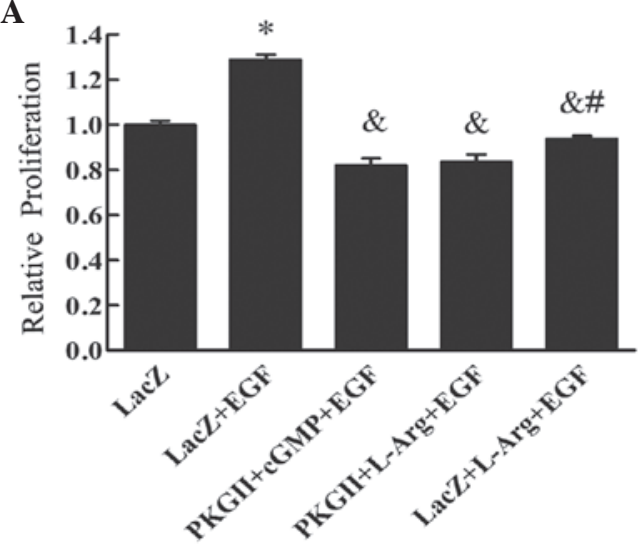

B

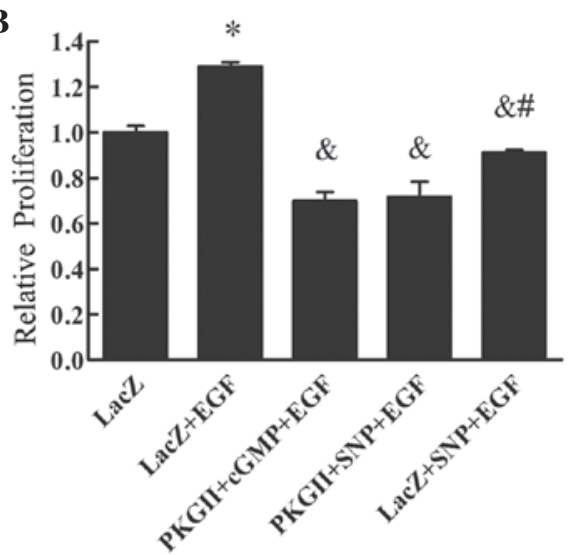

Figure 1. Results of the CCK-8 assay for (A) L-Arg and (B) SNP. AGS cells were infected with either Ad-LacZ or Ad-PKG II, serum-starved for 12 h, then stimulated with 8-pCPT-cGMP $(250 \mu \mathrm{M})$ for $1 \mathrm{~h}$, SNP $(1 \mathrm{mM})$ for $2 \mathrm{~h}$ or L-Arg $(2 \mathrm{mM})$ for $4 \mathrm{~h}$, and subsequently treated with EGF (100 ng/ml) for $24 \mathrm{~h}$. The proliferation of the cells was analyzed using the CCK- 8 kit and the relative proliferative activities are presented as means \pm standard deviation of three independent experiments. It was demonstrated that EGF treatment (100 ng/ml for $24 \mathrm{~h})$ promoted cell proliferation ( $\mathrm{P}<0.01 \mathrm{compared}$ with the Ad-LacZ group). The proliferative activity of the Ad-PKG II + SNP + EGF and the Ad-PKG II + L-Arg + EGF groups was markedly decreased ( ${ }^{\&} \mathrm{P}<0.01$ compared with the Ad-LacZ + EGF group). In addition, the inhibitory effect on proliferation of the Ad-PKG II + SNP + EGF and the Ad-PKG II + L-Arg + EGF groups was more prominent compared with that of the Ad-LacZ + SNP + EGF and Ad-LacZ + L-Arg + EGF groups $\left({ }^{\#} \mathrm{P}<0.05\right)$. CCK-8, Cell Counting Kit-8; Ad-LacZ, adenoviral vector encoding $\beta$-galactosidase cDNA; Ad-PKG II, adenoviral vector encoding PKG II; L-Arg, L-arginine; SNP, sodium nitroprusside; EGF, epidermal growth factor; cGMP, cyclic guanosine monophosphate; PKG II, type II cGMP-dependent protein kinase.

A
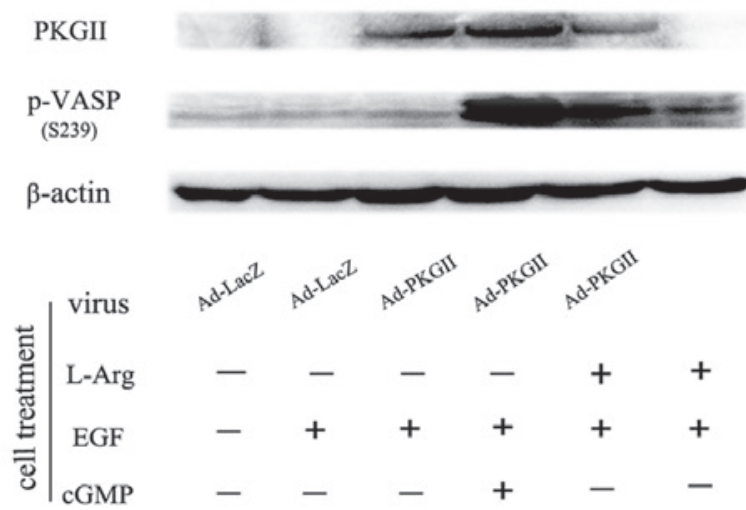

B

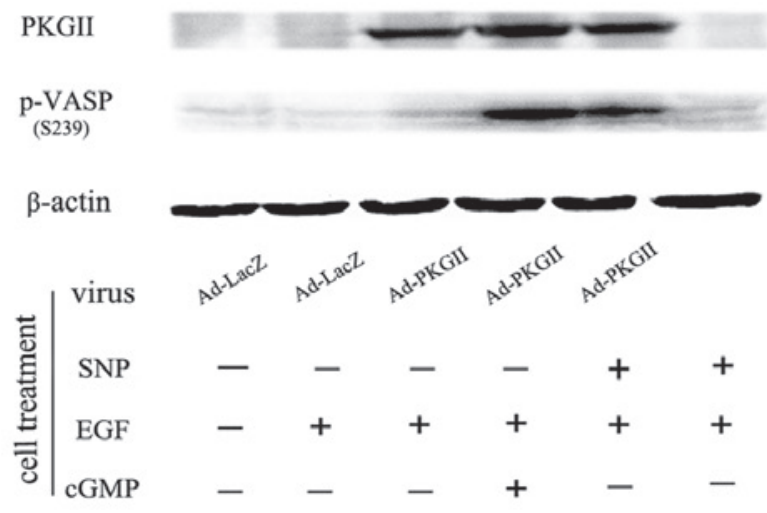

Figure 2. (A) L-Arg and (B) SNP increased the level of p-VASP Ser239. (A) AGS cells were infected with either Ad-LacZ or Ad-PKG II for 24 h and then serum-starved overnight. The Ad-LacZ group received no drug treatment. In the Ad-LacZ + EGF and Ad-PKG II + EGF groups, the cells were treated with EGF $(100 \mathrm{ng} / \mathrm{ml})$ for $5 \mathrm{~min}$. In the Ad-PKG II + cGMP + EGF group, the cells were incubated with 8-pCPT-cGMP $(250 \mu \mathrm{M})$ for $1 \mathrm{~h}$ and then stimulated with EGF (100 ng/ml) for $5 \mathrm{~min}$. In the Ad-PKG II + L-Arg + EGF and the L-Arg + EGF groups, the cells were treated with L-Arg (2 mM, 4 h) and then with EGF $(100 \mathrm{ng} / \mathrm{ml})$ for $5 \mathrm{~min}$. (B) The treatments of the former four groups were same as described in A. In the latter two groups, the cells were incubated with $1 \mathrm{mM}$ SNP for $2 \mathrm{~h}$, followed by EGF (100 ng/ml) for $5 \mathrm{~min}$ in the Ad-PKG II + SNP + EGF and the SNP + EGF groups. The cells were harvested and the extracts were subjected to western blotting with the corresponding antibodies, as described in Materials and methods. The results are representative of three independent experiments. L-Arg, L-arginine; p-VASP, phosphorylated vasodilator-stimulated phosphoprotein; Ad-LacZ, adenoviral vector encoding $\beta$-galactosidase cDNA; Ad-PKG II, adenoviral vector encoding PKG II; SNP, sodium nitroprusside; PKG II, type II cGMP-dependent protein kinase; EGF, epidermal growth factor; cGMP, cyclic guanosine monophosphatase.

proliferation was observed, as was in cells infected with Ad-PKG II, treated with 8-pCPT-cGMP and then with EGF (Fig. 1). These results indicated that, similar to the cGMP analogue 8-pCPT-cGMP, SNP and L-arginine were able to activate PKG II and exert an anti-proliferative effect on AGS cells highly expressing PKG II.

SNP and L-arginine increase the production of cGMP in AGS cells. Once NO is released, it activates sGC, thereby increasing the level of cGMP $(10,11)$. In this experiment, ELISA was performed to detect the level of cGMP in differently treated cells. The results demonstrated that, in AGS cells, the concentration of cGMP was increased by treatment with SNP or L-arginine in a dose- and time-dependent manner, confirming that SNP and L-arginine treatment increases the production of cGMP (Table I).

SNP and L-arginine increase the level of p-VASP Ser239. High levels of cGMP may activate PKG II and cause phosphorylation of the substrate protein of this kinase. VASP is a substrate of protein kinases, including PKGs, and its Ser239 residue is a target specific to PKG II $(12,13)$. In this experiment, we analyzed SNP- and L-arginine-induced activation of PKG II by detecting the level of p-VASP Ser239 by western 
Table I. SNP and L-arginine treatment increases the production of cGMP in AGS cells.

A, Effect of treatment by dose

\begin{tabular}{lcccc}
\hline & \multicolumn{4}{c}{ Dose $(\mathrm{mM})$} \\
\cline { 2 - 5 } Treatment & 0 & 1 & 2 & 4 \\
\hline SNP (2 h) & $18.15 \pm 0.3$ & $20.78 \pm 0.7^{\mathrm{a}}$ & $22.94 \pm 0.6^{\mathrm{a}}$ & $24.37 \pm 0.4^{\mathrm{a}}$ \\
L-arginine (4 h) & $14.97 \pm 0.5$ & $22.59 \pm 0.8^{\mathrm{a}}$ & $26.16 \pm 0.8^{\mathrm{a}}$ & $28.34 \pm 0.4^{\mathrm{a}}$ \\
\hline
\end{tabular}

B, Effect of treatment by time

Time (h)

\begin{tabular}{lcccc}
\cline { 2 - 5 } Treatment & 0 & 1 & 2 & 4 \\
\hline SNP $(1 \mathrm{mM})$ & $17.55 \pm 0.4$ & $20.93 \pm 1.0^{\mathrm{a}}$ & $23.26 \pm 0.5^{\mathrm{a}}$ & $25.10 \pm 0.9^{\mathrm{a}}$ \\
L-arginine $(2 \mathrm{mM})$ & $14.06 \pm 0.6$ & $20.90 \pm 1.1^{\mathrm{a}}$ & $24.63 \pm 1.0^{\mathrm{a}}$ & $27.51 \pm 0.6^{\mathrm{a}}$
\end{tabular}

Data are presented as means \pm standard deviation from three different experiments. ${ }^{\text {a }}<0.01 \mathrm{vs} .0 \mathrm{mM}$ or $0 \mathrm{~h}$. SNP, sodium nitroprusside; cGMP, cyclic guanosine monophosphate.

A

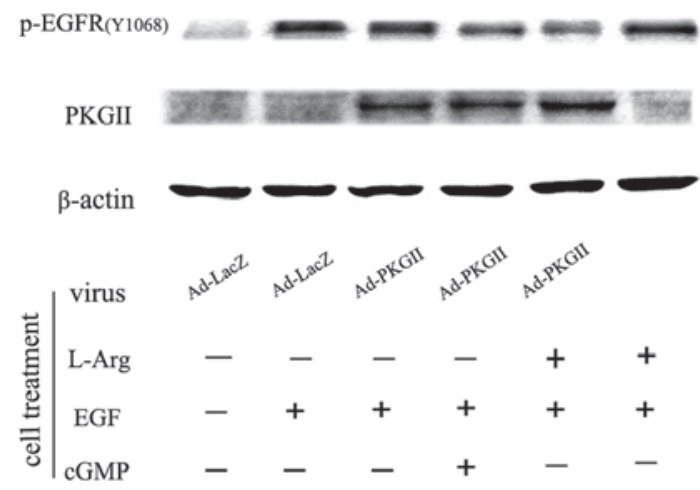

B p-EGFR(Y1068)

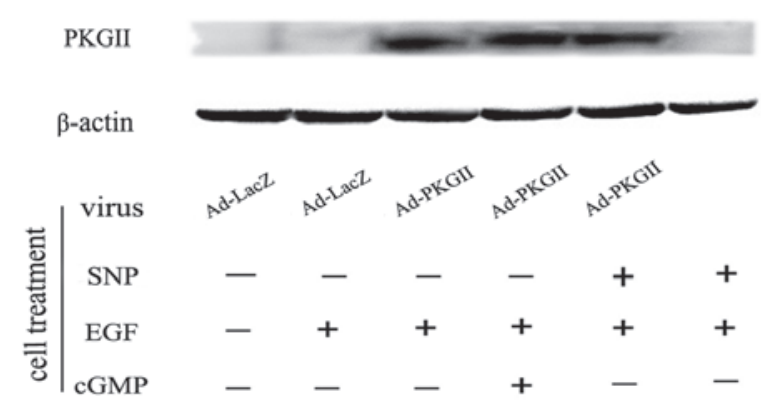

Figure 3. EGF-stimulated Tyr1068 phosphorylation of EGFR is blocked by PKG II activation induced by (A) L-Arg and (B) SNP. The AGS cells were treated as described in Fig. 2. Western blotting with an antibody against p-EGFR (Tyr1068) was used to detect the Tyr1068 phosphorylation of EGFR. The results are representative of three independent experiments. L-Arg, L-arginine; EGF, epidermal growth factor; EGFR, EGF receptor; PKG II, type II cGMP-dependent protein kinase; Ad-LacZ, adenoviral vector encoding $\beta$-galactosidase cDNA; Ad-PKG II, adenoviral vector encoding PKG II; SNP, sodium nitroprusside; cGMP, cyclic guanosine monophosphatase.

blotting. The results demonstrated that 8-pCPT-cGMP treatment $(250 \mu \mathrm{M}, 1 \mathrm{~h})$ increased the phosphorylation of VASP at Ser239. Treatment with SNP $(1 \mathrm{mM}, 2 \mathrm{~h})$ or L-arginine ( $2 \mathrm{mM}, 4 \mathrm{~h}$ ) also caused a significant increase of Ser239 phosphorylation of VASP (Fig. 2). These results indicated that SNP and L-arginine treatment leads to PKG II activation.

EGF-induced EGFR Tyr1068 phosphorylation is inhibited by SNP- or L-arginine-induced activation of PKG II. As a transmembrane tyrosine kinase, EGFR is dimerized and auto-phosphorylated by binding with ligands, such as EGF. Tyr1068 is one of the auto-phosphorylation sites of EGFR associated with the MAPK-mediated signaling pathway $(14,15)$. Our previous results demonstrated that PKG II inhibited EGF-induced Tyr1068 phosphorylation of EGFR $(7,8)$. The present study investigated whether the NO donor/precursor inhibited EGF-induced Tyr1068 phosphorylation of EGFR through activating exogenous PKG II. The results of the western blotting revealed that, in cells infected with Ad-LacZ and treated with EGF (100 ng/ml, $5 \mathrm{~min})$, the level of Tyr1068 phosphorylation of EGFR increased markedly (Fig. 3). In cells infected with Ad-PKG II and treated with SNP (1 mM, 2 h) or L-arginine (2 mM, 4 h), the EGF-induced increase of Tyr1068 phosphorylation of EGFR was efficiently inhibited. However, in cells without Ad-PKG II infection, treatment with SNP or L-arginine exerted no clear effect on EGF-induced Tyr1068 phosphorylation of EGFR. Therefore, it was confirmed that NO donors and precursors (SNP and L-arginine) inhibit EGF-induced Tyr1068 phosphorylation of EGFR through activating PKG II.

SNP and L-arginine inhibit EGF-stimulated phosphorylation of ERK1/2 at Thr202/Tyr204. When EGFR is phosphorylated at Tyr1068, it initiates MAPK/ERK-mediated signaling (16). 
A

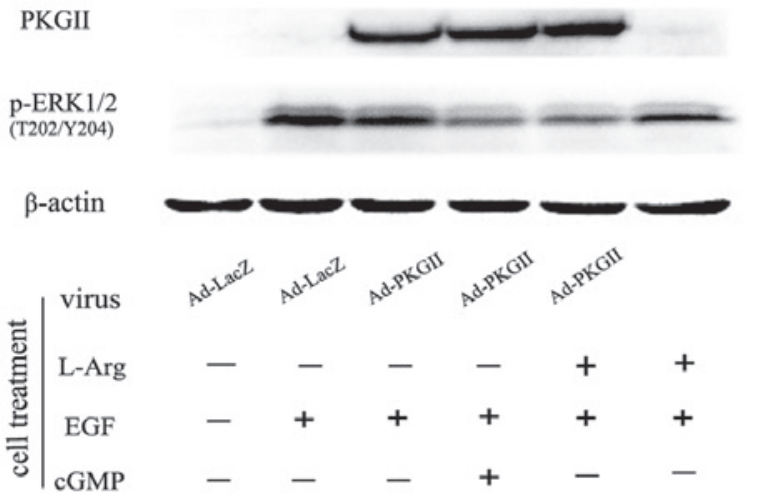

B

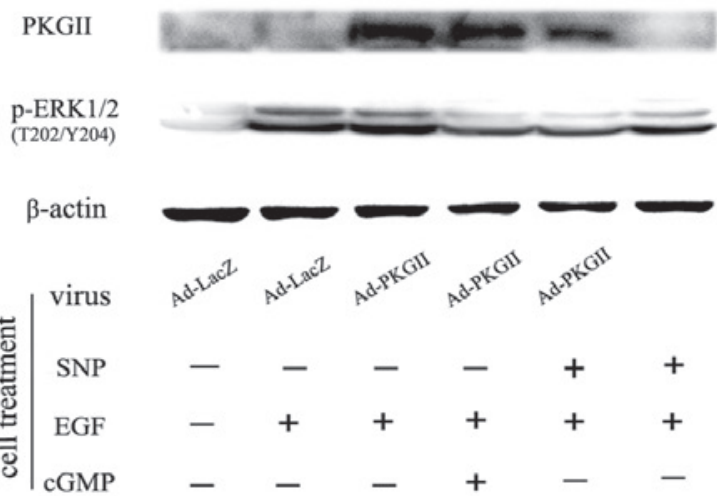

Figure 4. (A) L-Arg and (B) SNP inhibit EGF-stimulated phosphorylation of ERK1/2 at Thr202/Tyr204. The AGS cells were treated as described in Fig. 2. Western blotting with an antibody against p-ERK1/2 (Thr202/Tyr204) was applied to detect the phosphorylation of p-ERK1/2. The results are representative of three independent experiments. L-Arg, L-arginine; EGF, epidermal growth factor; PKG II, type II cGMP-dependent protein kinase; Ad-LacZ, adenoviral vector encoding $\beta$-galactosidase cDNA; Ad-PKG II, adenoviral vector encoding PKG II; SNP, sodium nitroprusside; PKG II, type II cGMP-dependent protein kinase; ERK1/2, extracellular signal-regulated kinase 1/2; cGMP, cyclic guanosine monophosphatase.

Phosphorylation of ERK1/2 at the Thr202/Tyr204 residues is one of the key events of the signaling process of this pathway $(17,18)$. Western blotting with an antibody against p-ERK1/2 (Thr202/Tyr204) was performed to detect the dual phosphorylation of ERK. The results demonstrated that EGF treatment (100 ng/ml, $5 \mathrm{~min}$ ) caused an obvious increase in the level of p-ERK1/2 (Thr202/Tyr204). However, the phosphorylation was efficiently inhibited by pre-infecting cells with Ad-PKG II and activating the enzyme by treatment with SNP (1 mM, 2 h) or L-arginine (2 mM, 4 h). Furthermore, in cells without Ad-PKG II infection, SNP (1 mM, 2 h) or L-arginine $(2 \mathrm{mM}, 4 \mathrm{~h})$ treatment also exerted a mild inhibitory effect on EGF-induced p-ERK1/2 (Fig. 4). Therefore, treatment with SNP or L-arginine alone has a mild inhibitory effect on p-ERK1/2. However, when the expression of PKG II was increased by Ad-PKG II infection, SNP and L-arginine treatment completely inhibited EGF-induced phosphorylation of p-ERK1/2 through the activation of PKG II.

\section{Discussion}

NO may be synthesized by three isoforms of NOS, namely neuronal, inducible (in macrophages) and endothelial NOS. Once released, NO diffuses through the cell membrane and enters the cytosol, where it meets the target protein, such as sGC $(19,20)$. NO may bind to the protoporphyrin ring of sGC, causing activation of the enzyme and leading to the formation of cGMP $(21,22)$. As an intracellular signaling molecule, cGMP plays an important role in the regulation of various cellular events and may exert its effects through PKGs, which catalyze the phosphorylation at serine/threonine residues on substrate proteins, thereby altering their activities (23).

In our previous experiments, it was demonstrated that PKG II blocked the EGF-induced activation of EGFR and inhibited EGFR-initiated signal transduction and the proliferation of gastric cancer cells $(6,7)$. To obtain a high activity of PKG II in cancer cells, which usually express this enzyme at a low level, Ad-PKG II was used to increase the expression of PKG II in these cells. The membrane-permeable cGMP analogue 8-pCPT-cGMP was required to activate PKG II. The present study was designed to identify a reagent to replace 8-pCPT-cGMP.

Since NO induces cGMP production, a NO donor and a $\mathrm{NO}$ precursor were selected to increase the content of $\mathrm{NO}$ in AGS cells infected with Ad-PKG II, with the intention of using endogenous cGMP to activate PKG II. The results of the ELISA revealed that the NO donor SNP and the NO precursor L-arginine caused a dose- and time-dependent increase of intracellular cGMP in the cells. The effect of SNP and L-arginine on PKG II activity was confirmed by detecting the phosphorylation of VASP, the serine/threonine residues of which are substrates for the PKA and PKG (24). There are three phosphorylation sites of VASP, namely Ser157, Ser239 and Tyr278 (13,25-27). Tao et al (13) reported that Ser239 was a key phosphorylation site of VASP for PKG II activation. Therefore, the level of p-VASP Ser239 was detected to reflect PKG II activity. The results demonstrated that, under treatment with cGMP, the level of p-VASP Ser239 was markedly increased in cells pre-infected with Ad-PKG II. Similar to cGMP, SNP and L-arginine also increased the level of p-VASP Ser239, causing PKG II activation in these cells.

In the present study, the inhibitory effects of SNP and L-arginine on EGF-induced proliferative signaling; the proliferation of gastric cancer cells infected with Ad-PKG II was also confirmed. When combined with EGF, EGFR is activated, which then recruits the effectors to its phosphorylated intracellular domain and initiates the downstream protein-mediated signaling. Among the phosphorylation sites, Tyr1068 is associated with the MAPK/ERK pathway (28). It was revealed that cGMP-induced PKG II activation blocks the EGF-induced phosphorylation of EGFR at Tyr1068. The present study revealed that treatment with SNP or L-arginine alone did not cause a distinct inhibition of EGF-induced Tyr1068 phosphorylation of EGFR in cells without Ad-PKG II infection. However, when PKG II was highly expressed following Ad-PKG II infection, SNP or L-arginine were able to efficiently inhibit EGF-induced Tyr1068 phosphorylation of EGFR. The effect of SNP and L-arginine on EGF/EGFR-induced signaling of the MAPK/ERK pathway was then further investigated. The results demonstrated that treatment with SNP or L-arginine 
alone exerted a mild inhibitory effect on the EGF-induced Thr202/Tyr204 phosphorylation of ERK1/2, which is a key signaling event of the MAPK/ERK pathway. This was also observed by Sang et al (29). However, when combined with Ad-PKG II infection, SNP and L-arginine treatment markedly inhibited the EGF-induced activation of p-ERK1/2, suggesting that SNP and L-arginine-induced NO/cGMP production exerts an effect on the activation of ERK, but not EGFR. However, through the activation of PKG II, SNP and L-arginine exerted inhibitory effects on EGFR and ERK activation and, therefore, exerted more distinct inhibitory effects on proliferative signaling. In conclusion, a NO donor and a NOS substrate may replace 8-pCPT-cGMP and activate PKG II by increasing the level of endogenous cGMP, providing an alternative method of activating this potential cancer inhibitory factor.

\section{Acknowledgements}

This study was supported by grants from the National Natural Science Foundation of China (nos. 81272755, 81201959 and 81001100); the Natural Science Foundation Project of Jiangsu Province (no. 12KJB310001); China Postdoctoral Science Foundation (no. 2014M561599); Postdoctoral Research Funding Plan in Jiangsu Province (no. 1401144C); and the Specialized Research Fund for Senior Personnel Program of Jiangsu University (no. 11JDG114). The authors would like to thank Dr Gerry Boss and Dr Renate Pilz of the University of California (San Diego, CA, USA) for providing the adenoviral constructs.

\section{References}

1. Bohme E and Schmidt HH: Nitric oxide and cytosolic guanylate cyclase: components of an intercellular signalling system. Z Kardiol 78 Suppl 6: 75-79, 1989.

2. Orstavik S, Natarajan V, Tasken K, Jahnsen T and Sandberg M: Characterization of the human gene encoding the type I alpha and type I beta cGMP-dependent protein kinase (PRKG1). Genomics 42: 311-318, 1997.

3. Orstavik S, Solberg R, Taskén K, et al: Molecular cloning, cDNA structure and chromosomal localization of the human type II cGMP-dependent protein kinase. Biochem Biophys Res Commun 220: 759-765, 1996.

4. Wells A: EGF receptor. Int J Biochem Cell Biol 31: 637-643, 1999.

5. Jiang H, Grenley MO, Bravo MJ, Blumhagen RZ and Edgar BA EGFR/Ras/MAPK signaling mediates adult midgut epithelial homeostasis and regeneration in Drosophila. Cell Stem Cell 8 : 84-95, 2011.

6. Chen YC, Ren F, Sang JR, Tao Y and Xu WR: Type II cGMP-dependent protein kinase inhibits proliferation of the gastric cancer cell line BGC-823. Mol Med Rep 3: 361-366, 2010

7. Wu Y, Chen Y, Qu R, Lan T and Sang J: Type II cGMP-dependent protein kinase inhibits EGF-triggered signal transduction of the MAPK/ERK-mediated pathway in gastric cancer cells. Oncol Rep 27: 553-558, 2012.

8. Lan T, Chen Y, Sang J, et al: Type II cGMP-dependent protein kinase inhibits EGF-induced MAPK/JNK signal transduction in breast cancer cells. Oncol Rep 27: 2039-2044, 2012.

9. Jiang L,Lan T, Chen Y, et al: PKG II inhibits EGF/EGFR-induced migration of gastric cancer cells. PLoS One 8: e61674, 2013.
10. Medeiros JV, Gadelha GG,Lima SJ, et al: Role of the NO/cGMP/K (ATP) pathway in the protective effects of sildenafil against ethanol-induced gastric damage in rats. Br J Pharmacol 153: 721-727, 2008.

11. Russo I, Doronzo G, Mattiello L, De Salve A, Trovati M and Anfossi G: The activity of constitutive nitric oxide synthase is increased by the pathway cAMP/cAMP-activated protein kinase in human platelets. New insights into the antiaggregating effects of cAMP-elevating agents. Thromb Res 114: 265-273, 2004.

12. Kwiatkowski AV, Gertler FB and Loureiro JJ: Function and regulation of Ena/VASP proteins. Trends Cell Biol 13: 386-392, 2003.

13. Tao Y, Gu YJ, Cao ZH, et al: Endogenous cGMP-dependent protein kinase reverses EGF-induced MAPK/ERK signal transduction through phosphorylation of VASP at Ser239. Oncol Lett 4: 1104-1108, 2012

14. Wheeler S, Siwak DR, Chai R, et al: Tumor epidermal growth factor receptor and EGFR PY1068 are independent prognostic indicators for head and neck squamous cell carcinoma. Clin Cancer Res 18: 2278-2289, 2012.

15. Yamazaki T, Zaal K, Hailey D, Presley J, Lippincott-Schwartz J and Samelson LE: Role of Grb2 in EGF-stimulated EGFR internalization. J Cell Sci 115: 1791-1802, 2002

16. Rojas M, Yao S and Lin YZ: Controlling epidermal growth factor (EGF)-stimulated Ras activation in intact cells by a cell-permeable peptide mimicking phosphorylated EGF receptor. J Biol Chem 271: 27456-27461, 1996.

17. Saito T, Okada S, Ohshima K, et al: Differential activation of epidermal growth factor (EGF) receptor downstream signaling pathways by betacellulin and EGF. Endocrinology 145: 4232-4243, 2004.

18. Kolch W: Meaningful relationships: the regulation of the Ras/Raf/MEK/ERK pathway by protein interactions. Biochem J 351: 289-305, 2000.

19. Dumitrescu C, Biondi R, Xia Y, et al: Myocardial ischemia results in tetrahydrobiopterin (BH4) oxidation with impaired endothelial function ameliorated by BH4. Proc Natl Acad Sci USA 104: 15081-15086, 2007.

20. Knowles RG and Moncada S: Nitric oxide synthases in mammals. Biochem J 298: 249-258, 1994.

21. Koesling D, Russwurm M, Mergia E, Mullershausen F and Friebe A: Nitric oxide-sensitive guanylyl cyclase: structure and regulation. Neurochem Int 45: 813-819, 2004.

22. Bruckdorfer R: The basics about nitric oxide. Mol Aspects Med 26: 3-31, 2005.

23. Madhusoodanan KS and Murad F: NO-cGMP signaling and regenerative medicine involving stem cells. Neurochem Res 32: 681-694, 2007.

24. Russo I, Viretto M, Doronzo G, et al: A short-term incubation with high glucose impairs VASP phosphorylation at serine 239 in response to the nitric oxide/cGMP pathway in vascular smooth muscle cells: role of oxidative stress. Biomed Res Int 2014: 328959, 2014

25. Lambrechts A, Kwiatkowski AV, Lanier LM, et al: cAMP-dependent protein kinase phosphorylation of EVL, a Mena/VASP relative, regulates its interaction with actin and $\mathrm{SH} 3$ domains. J Biol Chem 275: 36143-36151, 2000.

26. Butt E, Abel K, Krieger M, et al: cAMP- and cGMP-dependent protein kinase phosphorylation sites of the focal adhesion vasodilator-stimulated phosphoprotein (VASP) in vitro and in intact human platelets. J Biol Chem 269: 14509-14517, 1994.

27. Tao Y, Chen YC, Sang JR and Xu WR: Phosphorylation of vasodilator stimulated phosphoprotein is correlated with cell cycle progression in HeLa cells. Mol Med Rep 3: 657-662, 2010.

28. Roux PP and Blenis J: ERK and p38 MAPK-activated protein kinases: a family of protein kinases with diverse biological functions. Microbiol Mol Biol Rev 68: 320-344, 2004.

29. Sang JR, Chen YC and Tao Y: Nitric oxide inhibits gastric cancer cell growth through the modulation of the Akt pathway. Mol Med Rep 4: 1163-1167, 2011. 